\title{
Works Councils and Organizational Gender Policies in Germany
}

\author{
Uwe Jirjahn \\ University of Trier, GLO and IZA \\ Jens Mohrenweiser \\ Bournemouth University
}

\begin{abstract}
While education and labor force participation of women have been increased, there is still a substantial gender gap in labor market opportunities. This gives rise to the question of what factors lead employers to promote work-family balance and gender equality. We address this question by examining the influence of works councils on the gender policies of establishments in Germany. Using data of the IAB Establishment Panel, we find that the incidence of a works council is on average associated with an increased likelihood that an establishment provides family-friendly practices and promotes equal opportunities of men and women. This finding also holds in a recursive multivariate probit model that accounts for potential endogeneity of works council incidence. However, our estimates also show that the influence of works councils is heterogeneous. Performing separate estimate by collective bargaining status, we find a significant influence of works councils only for establishments covered by an industry-level collective bargaining agreements, but not for establishments covered by firm-level agreements or establishments not covered by collective bargaining.
\end{abstract}

JEL Classification: J13, J16, J52, J53.

Keywords: Non-union employee representation, works councils, gender equality, workfamily balance, equal opportunities, organizational gender policies.

Corresponding Author: Uwe Jirjahn, Universität Trier, Fachbereich IV, Lehrstuhl für Arbeitsmarktökonomik, Universitätsring 15, 54286 Trier, Germany, Email: jirjahn@unitrier.de 


\section{Introduction}

Gender equality is a key topic in the policy debate in many countries (European Commission 2016, United Nations Human Rights Council 2011, United Nations Office at Geneva 2016 and World Bank 2012). While education and labor force participation of women have increased, there is still a substantial gender gap in labor market opportunities (Blau and Kahn 2017). Women have more employment interruptions and shorter working hours (Albrecht et al. 1999, Cebrìan and Moreno 2015, European Foundation for the Improvement of Living and Working Conditions 2013). They work in occupations that are different from those of men (European Commission 2009), receive less employer provided training (OECD 2003), and are underrepresented in leadership positions (Smith et al. 2013). Moreover, there still exists an unexplained gender wage gap. Women get paid less for the same personal and job characteristics (Arulampalam et al. 2007, Blau and Kahn 2003, Christofides et al. 2013).

The patterns of gender inequality also hold for Germany. There is a substantial unexplained gender wage gap in Germany. While the estimated gap varies from study to study, there is little doubt that it exists. For example, Holst and Busch (2008) estimate an unexplained gender pay gap of 17 percent among full-time employees. ${ }^{1}$ There is also evidence of a gender training gap (Campaner et al. 2018, Fitzenberger and Muehler 2015) and occupational gender segregation (Grundert and Mayer 2012). Women are under-represented in upper service and skilled manual occupations. They are over-represented in non-manual routine occupations. Furthermore, a substantial gender leadership gap exists in Germany with the gap being particularly pronounced in top management positions (Kohaut and Möller 2017).

On the one hand, gender differences in labor market opportunities may reflect women's disproportionate responsibility for family. This does not only imply that women have more family-related employment interruptions, but also that they need more flexibility between work and family when they participate in the labor force (Goldin 2014a, Heywood and Jirjahn 2002). 
Thus, they sort and are sorted into jobs that allow combining work and family. On the other hand, the gender differences may reflect stereotypes and discrimination (Becker 1957, Goldin 2014b, Goldin and Rouse 2000, Janssen et al. 2016). ${ }^{2}$ For example, male managers may view it as a threat to their own gender identity if they have female subordinates receiving high wages (Akerlof and Kranton 2000). ${ }^{3}$ Hence, they may feel the need to mistreat their female subordinates to rebalance utility.

The gender differences in labor market outcomes give rise to the question of what factors lead employers to provide family-friendly practices and to implement policies promoting equal opportunities of men and women. For Germany, there is evidence that familyfriendly and equal opportunity practices are associated with higher well-being of working mothers (Lauber and Storck 2019) and lower gender inequality within establishments (Huffman et al. 2017). Thus, it is important to understand the factors influencing the provision of these organizational gender policies (OGPs).

Against this background, we examine the influence of works councils on OGPs in Germany. Works councils provide a mechanism for participation in decision making. They are a key institution of nonunion employee representation in many West European countries. Compared to their counterparts in most of the other countries, works councils in Germany have acquired quite extensive powers. In Germany, the creation of a works council depends on the initiative of the establishment's workforce. Hence, works councils are not present in all eligible establishments. This allows us to conduct a within-country study by comparing the OGPs of establishments with and without a works council.

We use data from the IAB Establishment Panel. The data provide information on two types of OGPs. First, they contain information on whether or not an establishment has implemented measures to promote the advancement of women. These measures can include, for example, mentoring programs or action plans for women. They may help overcome 
stereotypes and discrimination within the establishment and, thus, can contribute to equal opportunities of women and men. Second, the data provide information on the use of a series of practices that enable employees to combine family and work commitments. Some practices such as support with child care help relieve employees of family responsibilities and, hence, allow them to spend more time at work. Other practices such as flextime or home office enable employees to fulfill their family responsibilities. Women are potentially the main beneficiaries of these practices as they are disproportionately responsible for family. ${ }^{4}$

Our estimates show that establishments with a works council are more likely to provide various family-friendly practices and are more likely to promote the advancement of women. The findings also hold when accounting for the endogeneity of works councils. We estimate a recursive multivariate probit model to address the issue of endogeneity. The estimated influence of works councils is even stronger when that issue is accounted for. The estimates show a negative correlation of unobserved factors influencing the incidence of a works council and unobserved factors driving the use of OGPs.

Our findings support theoretical considerations suggesting that works councils help overcome the underprovision of family-friendly and equal opportunity practices. Prejudiced employers may not voluntarily provide OGPs. In this case, works councils use their bargaining power to push through family-friendly and equal opportunity practices. Even if employers are unprejudiced against women, incomplete information about employees' preferences, commitment problems of the employer and supervisor opportunism at various layers of hierarchy can result in an underprovision of family-friendly and equal opportunity practices. In that case, works councils can contribute to an increased provision by communicating employee preferences to the employer, solving commitment problems and reducing supervisor opportunism. Of course, works councils should only have a substantial impact on OGPs if they take women's interests into account. We find that works councils are positively associated with 
each of the practices examined. This suggests that works councils indeed take women's interests into account.

We also examine whether the influence of works councils on OGPs depends on circumstances and type of establishment. Our estimates suggest that a positive influence of works councils on OGPs can be particularly found in establishments covered by industry-level collective bargaining agreements, but not in establishments covered by firm-level agreements or in uncovered establishments. These findings conform to the notion that the functioning of works councils depends on the moderating role of unions and collective bargaining. Works councils are more effective in shaping the personnel policy of establishments when basic distributional conflicts are settled outside the establishment by unions and employers' association.

Our examination contributes in several ways to the literature. An increasing number of studies have examined the influence of works councils on outcomes such as productivity, profitability, and innovation (Jirjahn and Smith 2018). The influence of works councils on gender issues and particularly on OGPs has received little attention. There is some evidence that works councils contribute to a smaller gender wage gap within establishments (Gartner and Stephan 2004, Heinze and Wolf 2010). Works councils appear to decrease profits that are due to wage discrimination of women while they increase profits that are due to cooperation (Jirjahn 2011). These findings give rise to the question of how works councils contribute to more gender equality. Our study suggests one possible channel. Works councils foster the implementation of measures that promote the advancement of women.

Furthermore, our examination is related to a study by Heywood and Jirjahn (2009) showing a positive link between works councils and various family-friendly practices. Our examination differs in at least three respects from that study. First, we account for the endogeneity of works council incidence. Second, while Heywood and Jirjahn's study focuses 
only on family-friendly practices, our study also takes equal opportunity practices into account. Third, Heywood and Jirjahn consider the year 2002. We provide fresh evidence for the years 2012 and 2016.

On a broader scale, our examination is also related to studies on unions and OGPs in Anglo-Saxon countries. Those studies obtain mixed results. For Australia (Bardoel et al. 1999), Canada (Fakih 2014) and the U.S. (Deitch and Huffman 2001, Glass and Fujimoto 1995, Osterman 1995), there is little evidence that unionization has a positive influence on a broader array of family-friendly practices. By contrast, for Britain, Budd and Mumford (2004, 2006) obtain significantly positive influences of unions on the provision of parental leave, job sharing and child care subsidy. However, examining the determinants of equal opportunity practices, Perotin et al. (2003) find a significantly negative influence of unionization in Britain and no influence in Australia. Thus, more evidence is certainly warranted. First, the role of worker representation is likely to depend on the respective industrial relations system of a country. Germany has a system of industrial relations sufficiently different to command attention of the scholars and policy makers interested in employee representation. Industrial relations in Germany are characterized by a dual structure of employee representation with both unions and works councils. Works councils provide a highly developed mechanism for nonunion employee representation and, thus, have functions distinct from those of unions. Second, previous studies on OGPs have not considered the potential endogeneity of worker representation. Our examination on works councils in Germany suggests that a positive influence of worker representation on OGPs is underestimated if the issue of endogeneity is not accounted for. 


\section{Institutional Framework}

The dual structure of employee representation in Germany involves both works councils and unions. Collective bargaining agreements are usually negotiated between unions and employers' associations on a broad industrial level. They regulate wage rates and general aspects of the employment contract. Establishments are covered by a collective bargaining agreement if they are members of an employers' association. The share of establishments covered by firm-level agreements is small.

Works councils provide a highly developed mechanism for establishment-level participation in decision making. Their rights are defined in the Works Constitution Act (WCA). The law states that works councils be elected by the workforce of establishments with five or more employees. However, their creation depends on the initiative of the establishment's workforce. Works councils are designed to increase joint establishment surplus rather than to redistribute the surplus. The WCA does not allow wage negotiations. Works council and employer are obliged by law to cooperate "in a spirit of mutual trust ... for the good of the employees and of the establishment." Works councils and employers are not allowed to engage in activities that interfere with the peace within the establishment. Works councils do not have the right to strike and employers are barred from obstructing the activities of works councils.

The powers of works councils are quite broad. On a set of issues, they have full codetermination rights (i.e., rights to coequal participation in the design and implementation of policy). These issues include, for example, the introduction of new payment methods, the fixing of job and bonus rates, the allocation of working hours, the introduction and use of technical devices designed to monitor employee performance, and up- and down grading. In these areas management cannot take action without the agreement of the works council. The councils have less strong consultation rights in matters such as changes in equipment and working methods 
that affect job requirements. Their participation rights in financial and economic matters cover information provision.

Works councils also have rights in gender- and family-related matters. The WCA provides that councils shall promote both gender equality and reconciliation of work and family. Moreover, the WCA specifies a gender quota for works councilors. The gender that is in the minority within the establishment must be represented in the council at least according to its proportion of the workforce. As women, on average, account for a smaller share of employees than men, this quota seeks to improve the representation of women in works councils.

However, it is important to note that the behavior of works councils is not completely determined by the letter of the law. Thus, their functioning cannot be immediately derived from a reading of legislation. Works councils have scope to set their own agenda and to decide which goals they pursue. Moreover, cooperativeness of the employer can influence the functioning of works councils (Jirjahn and Smith 2006). Hence, it is an open question whether or not works councils fulfill all of the duties provided by the WCA. In the end, only empirical research can reveal the functioning of works councils in practice.

\section{Theoretical Background Discussion}

Works councils can have an influence on OGPs for several reasons. Codetermination and information rights increase employees' bargaining power and provide opportunities to monitor the employer. This enables employees to push through work-family balance and gender equality against prejudiced employers.

Unprejudiced employers may be to some extent willing to invest in family-friendly and equal opportunity practices in order to reduce personnel turnover, foster employee motivation and increase productivity. If employees prefer a higher level of work-family balance and 
gender equality, they may make concessions and, for example, implicitly pay for it through higher effort. However, there can be a series of organizational failures resulting in an underprovision of family-friendly and equal opportunity practices even when the top management of the firm is unprejudiced. Employee representation has the potential to mitigate these failures by providing information about employees' preferences, solving commitment problems of the employer and reducing supervisor opportunism. ${ }^{5}$

However, the influence of works councils on OGPs can be uncertain. The extent to which works councils are positively associated with increased work-family balance and gender equality depends on whether or not they take the interests of female employees into account. Moreover, the influence of works councils on OGPs may depend on the moderating role of collective bargaining coverage.

\subsection{Reducing Employer Discrimination}

The information and consultation rights of the works council increase transparency and enable the council to monitor the employer. Increased transparency makes it more difficult for a prejudiced employer to hide discrimination and puts pressure on the employer to adopt practices promoting gender equality. Moreover, the council can use its codetermination rights to negotiate equal opportunity and family-friendly practices. The council may even use its codetermination rights to obtain employer concessions on issues where it has no legal powers. If employer and works council fail to reach an agreement on those issues, the council can threaten to be uncooperative in areas where its consent is necessary. Altogether, codetermination rights increase the bargaining power of the works council. This can enable the council to push through family-friendly and equal opportunity practices against a prejudiced employer. 


\subsection{Communicating Employees’ Preferences}

Even if the employer is not prejudiced against women, organizational failures can result in a suboptimal provision of OGPs. Lack of sufficient information about employees' preferences can be one reason for a suboptimal personnel policy. Works councils may help overcome this problem by serving as a collective voice institution. This collective voice institution aggregates employees' preferences and communicates the aggregated preferences to the employer, helping optimize personnel policy (Askildsen et al. 2006, Doucouliagos et al. 2017, Freeman 1976, Freeman and Medoff 1979). Such optimization of personnel policy is unlikely to be achieved through individual voice.

Aghion and Hermalin (1990) use the example of family-friendly practices to illustrate that individual voice is indeed not effective in the context of OGPs. Asymmetric information can lead to a pooling equilibrium resulting in an inefficient level of family-friendly practices. Female employees differ in their probabilities of becoming pregnant and so being intensive users of family-friendly benefits, if they were to be provided. In the pooling equilibrium, neither women with low nor high probability of pregnancy express a desire for family-friendly benefits. Women with a low probability of pregnancy place low value on the benefits while women with a high probability anticipate that signaling their higher probability of using these benefits will result in employer sanctions. The sanctions can include reduced career opportunities or outright dismissals.

Such sanctions may be plausible to the extent that the employer underestimates total demand for family-friendly practices from the workforce and fears excessive use by single employees (Heywood and Jirjahn 2009). For example, maternity leave, flexible scheduling, and other practices involving fixed costs in their implementation and administration require a minimum number of employees to be efficiently provided. Assuming other employees do not reveal their preferences, each individual woman has no incentive to signal her own preference. 
Thus, even given a sufficiently large number of interested employees, coordination and communication problems among employees may limit their ability to jointly express this interest. The resulting inefficient equilibrium within the firm fails to provide family-friendly practices.

This inefficient equilibrium may be remedied with a collective voice institution that serves to increase communication and coordination. Aggregated preferences about familyfriendly and equal opportunity practices can be among those communicated to the employer. Collective voice replaces the fear employees might have in revealing their individual preferences. Moreover, the collective voice institution provides the employer a better assessment of the value of these practices. Such better assessment is likely to increase the employer's willingness to implement the practices. Furthermore, improved communication between employees and employer can improve the structuring of the practices so that they better match the employees' needs. This makes their realization and longevity more likely.

\subsection{Solving Commitment Problems}

The possibility of employer opportunism is a second source of organizational failure. Opportunities for employer opportunism result from incomplete labor contracts. Many of the promises made by the employer to employees are implicit. They are not explicitly spelled out in the labor contract. Thus, employees are at risk that the employer does not keep the promises and reneges on the implicit contract. The consequence of potential employer opportunism is that employees withhold effort and cooperation when the employer cannot credibly commit to take their interests into account. The codetermination rights of works councils can help solve commitment problems of the employer and increase employees' trust (Freeman and Lazear 1995, Jirjahn 2009, 2018). Thus, establishment-level codetermination provides a mechanism 
for negotiating human resource management practices that otherwise cannot be implemented because of lack of trust and cooperation.

Lack of trust can also play role in OGPs. On the one hand, employees may anticipate that family-friendly and equal opportunity practices are implicitly coupled with an unjustified intensification of work. On the other hand, they may be concerned that the employer does not undertake the necessary investments to make the practices work. For example, there can be distrust in the quality of employer provided childcare (Peus 2006). Similarly, employees may be concerned that the employer will not assign clear responsibilities for a mentoring program and will not conduct systematic evaluation of the program. At the extreme, there is the fear that the program is purely symbolic. As a consequence, the program will have no motivational effects and does not receive support from the employees.

A works council acting as a contract enforcer helps ensure that the employer keeps the promises made about providing work-family balance and gender equality (Heywood and Jirjahn 2009). The council can make sure that family-friendly and equal opportunity practices do not entail an unjustified intensification of work and the employer undertakes the necessary investments to make the practices work. This increases employees' trust in the credibility of the practices so that the practices have stronger effects in motivating the employees. As a consequence, the employer is more interested in implementing the practices when a works council is present.

\subsection{Reducing Supervisor Opportunism}

So far we have considered the simple employer-employee dichotomy. However, the issue of opportunism goes beyond this dichotomy. Information asymmetries imply that supervisors at various levels of hierarchy within the firm have discretionary power, allowing them to pursue their own goals. Supervisor opportunism can also play a role in family-friendly and equal 
opportunity practices. Supervisors may not allow their subordinates to use family-friendly practices (e.g., flexible hours) even when formally offered by the employer (Eaton 2003). They may hide information about the availability of family-friendly practices from their subordinates or penalize subordinates who use the practices (Park et al. 2019).

Similarly, equal opportunity practices (e.g., mentoring programs) may leave scope for opportunism and discrimination by supervisors. Supervisors may still have discretion in evaluating the performance of male and female subordinates (Castilla 2008, Castilla and Benard 2010). Equal opportunity practices can even have unintended adverse effects. They can give the impression of objectivity hiding biased evaluations of supervisors.

Employee representation through works councils reduces supervisor opportunism as it provides a channel for monitoring supervisors and enables communication between employees and top decision makers that is not filtered by immediate supervisors (Kaufman and Levine 2000, Smith 1991). This increases procedural fairness and employees' trust in organizational gender policies so that these policies are more effective (Heywood and Jirjahn 2009, Park et al. 2019).

\subsection{Taking Women's Interests into Account}

Altogether, works councils have the potential to promote family-friendly and equal opportunity practices. However, the extent to which works councils have a positive influence on the provision of these practices is likely to depend on whether or not they take the interests of women into account. One might argue that the agenda of a works council rather reflects concerns of dominant groups within the establishment - male, full time, native-born employees. These characteristics traditionally have been viewed as those of the 'universal employee'. This would suggest that women fall more or less outside the scope of works councils. In this case, works councils may still have some positive influence on practices that 
also benefit men (e.g., flexible work schedules). Yet, the influence of works councils on OGPs would be rather limited. We should not find a positive influence on practices which do not benefit men (e.g., equal opportunity practices).

By contrast, if works councils take women's interests into account, we should find a positive influence on a broad array of OGPs. In that case, works councils should also positively influence practices that overwhelmingly benefit female employees. From a theoretical viewpoint, there are two reasons suggesting that works councils may indeed take women's interest into account.

First, a works council may foster notions of fairness and solidarity within the workforce to increase cohesiveness (Jirjahn and Kraft 2007, Levine 1991). Increased cohesiveness means that the council obtains the support necessary for strengthening its bargaining power and, hence, for a successful representation of employee interests. Thus, notions of fairness and solidarity could imply that the works council to some extent accounts for women's interests and promotes work-family balance and gender equality even if it represented mainly the concerns of male employees.

Second, it has to be taken into account that the WCA provides a gender quota for works councilors. A gender quota may facilitate strategies of particular interest to women and could result in a gendered bargaining agenda (Dickens 2000, Heery 2006, Kirsch and Blaschke 2014). Of course, the presence of women among works councilors does not guarantee that the works council promotes gender equality. There could be a difference between 'being there' and 'making a difference' (Cockburn 1989, Cunnison and Stageman 1993). Securing access to positions for women does not necessarily alter the rules and culture of industrial relations within the establishment. Men might still hold power within the works council. Experimental evidence suggests that women are less likely to initiate negotiations and are treated differently 
when they attempt to negotiate (Bertrand 2011). This may reflect that women are less socially accepted when they behave in a stereotypically masculine way.

Altogether, the question of whether or not works councils take the interests of women into account can only be answered empirically. If works councils mainly represent the interests of male workers, we should find a rather limited or possibly even no influence of works council presence on OGPs. By contrast, if works councils take women's interests into account, we should find a positive influence on a broad array of OGPs.

\subsection{The Moderating Role of Collective Bargaining}

We recognize that the influence of works councils on OGPs may also depend on moderating circumstances. Previous research has shown that particularly collective bargaining coverage plays a moderating role in the functioning of works councils (Heywood and Jirjahn 2002, 2009, Hübler and Jirjahn 2003, Jirjahn 2017, Kriechel et al. 2014, Pfeifer 2011, Müller 2011). Works councils have a stronger positive influence on personnel policy and performance among establishments covered by collective bargaining agreements. This holds for indicators such as performance pay, training, employee retention, productivity and even profitability. These findings conform to the notion that works councils are more effective in shaping the personnel policy of establishments and contributing to economic success when basic distributional conflicts are settled outside the establishment by unions and employers' associations. Against this background, we anticipate that a positive influence of works councils on OGPs should be more pronounced in establishments covered by an industry-level bargaining agreement.

\section{Data and Variables}

\subsection{The Data}

We draw data from the IAB Establishment Panel (Ellguth et al. 2014). This is a representative 
sample of establishments (with at least one employee covered by social insurance) from all sectors in the German economy. The sample is stratified according to establishment size, industry and federal state. Note that we include variables for the stratification characteristics in the estimations so that we do not need to use weighted regressions (Winship and Radbill 1994).

The IAB is the research institute of the German Federal Employment Agency. The institute contracts with Infratest Sozialforschung, a professional survey and opinion research institute, to conduct the interviews. The data are collected on the basis of a questionnaire and follow-up personal interviews with the owner or top manager of the establishment. Each year since 1993 (1996), the IAB Establishment Panel has surveyed several thousand establishments in Western (Eastern) Germany. Basic information on the establishment and a core set of questions are asked annually. Additional topics are introduced in specific waves.

We pool data from the waves 2012 and 2016. These waves provide detailed information on family-friendly and equal opportunity practices. Because labor market settings and incentives differ between the private and the public sector (Burgess and Metcalfe 2000, Burgess and Ratto 2003), we exclude the public sector (government agencies). For a related reason we also exclude non-profit organizations. ${ }^{6}$ Furthermore, as the WCA only applies to establishments with at least five employees, the analysis is restricted to establishments meeting this minimum size. After eliminating cases for which full information is not available, the analysis is based on 16,391 observations from 12,311 establishments. $^{7}$

\subsection{Dependent Variables}

Under the heading 'equal opportunities', the survey asks if the establishment has implemented measures to promote work-family balance and equal opportunities of men and women. Directly related to equal opportunities, the survey provides information on whether the establishment has implemented measures to promote the advancement of women. These measures can, for 
example, include, mentoring programs, training of female employees, action plans for women, and plans to increase the share of female employees. This may help overcome stereotypes and discrimination of women within the establishment.

Moreover, the survey provides information on a series of family-friendly practices, namely support with child care, flexible work schedules for employees with care responsibilities, provision of support to employees with relatives needing care, provision of support to employees on parental leave, and participation in a network of family-friendly companies. Women are potentially the main beneficiaries of these practices as they are disproportionately responsible for family.

Support with child care can include the provision of on-site child care, cooperation with child care facilities or financial contributions towards child care. Support with child care helps relieve employees of family responsibilities and, hence, allows them to spend more time at work (Heywood et al. 2007). By contrast, flexible work arrangements such as flextime (flexibility with respect to the days of work or with respect to the beginning or end of the work day) or telecommuting and home office (employees can work in facilities away from their job sites) enable employees to fulfill their family responsibilities. Support to employees with relatives needing care includes, for example, cooperation with care homes or advisory services for the employees. Measures to support employees on parental leave may include information provision or training programs. These measures are thought to improve the quality of employees' leave and also increases the chance that they will return to their employer. Finally, participation in a network of family-friendly companies enables information exchange between employers and, thereby, helps improve their family-friendly policies.

Table 1 provides definitions and descriptive statistics of the key variables. Employers most frequently provide flexible work schedules to support employees with care responsibilities (43 percent). This practice is followed by provision of support to employees on 
parental leave (17 percent), provision of support with child care (14 percent) and provision of support to employees with relatives needing care $(9$ percent). The provision of measure to promote the advancement of women ( 4 percent) and the participation in a cross-company network of family-friendly firms (3 percent) have the lowest frequencies.

Table A1 in the Online Appendix shows the distribution of the number of OGPs provided. About 58 percent of the employers provide at least one OGP. Most frequently, employers provide only one or two OGPs. There are only 0.2 percent of all employers providing all of the seven OGPs. The average number of OGPs is equal to 0.97 in the total sample. It equals 1.86 if we only consider employers providing at least one OGP.

\subsection{Key Explanatory Variables}

Our explanatory variable of primary interest is a dummy equal to 1 if a works council is present in the establishment. There are about 25 percent of observations with a works council. As discussed, the creation of a council depends on the initiative of the establishment's workforce. Thus, works councils are not present in all eligible establishments so we can compare establishments with and without a works council.

In order to isolate the role of works councils from other industrial relations factors, we include variables for the coverage by an industry-level and a firm-level collective bargaining agreement. We also include a dummy for establishments that are not formally bound to collective bargaining contracts, but pursue an orientation at those contracts. From a theoretical viewpoint, the influence of collective bargaining coverage on OGPs is not clear. On the one hand, unions may include OGPs in the bargaining agenda implying a positive influence of collective contracts on the provision of OGPs (Flüter-Hoffmann 2005). On the other hand, specifically, centralized collective bargaining may impose restrictions on the establishments' flexibility (Lindbeck and Snower 2001) entailing a negative influence on OGPs. 
Furthermore, we control for the use of alternative forms of nonunion employee representation. ${ }^{8}$ Alternative forms of employee representation such as staff spokesmen and round tables are voluntarily implemented by the employer and not mandated by law (Stettes 2008). Similar to works councils, they provide channels for improved communication between management and workers. Alternative forms of employee involvement may be seen as ingredients to a high-commitment work system that aims at fostering workers' willingness to engage themselves and offer their ideas and knowledge (Osterman 1995). Such improved information sharing may help implementing OGPs. However, alternative forms of employee representation have no legally defined rights and are far less powerful than works councils. Thus, it is an open question whether they can play a role similar to that of works councils.

Employers may to some extent invest in OGPs with or without employee representation in order to reduce personnel fluctuation and to improve productivity. The costs and benefits of this investment depend on a series of circumstances. Specifically, the share of female employees should have a positive influence on the provision of family-friendly and equal opportunity practices. A higher share of female employees means that the establishment has a higher share of employees valuing and desiring these practices.

\subsection{Further Explanatory Variables}

The dataset allows to control for a variety of other factors potentially having an influence on OGPs. ${ }^{9}$ The definition and descriptive statistics of the additional control variables are shown in the Table A2. The structure of the workforce is accounted for by the shares of part-timers, temporary agency workers, apprentices, skilled workers, and university graduates. We also control for establishment size and multi-establishment firms to take the scale of production into account. The establishment's hours policy is captured by variables for usual weekly hours, overtime use and shift work. The nature of production is controlled for by the vintage of 
production technology and the establishment's innovativeness. The managerial environment is accounted for by variables for foreign owners and the share of female top managers as a proportion of all top managers. Finally we include twelve industry dummies, fifteen federal state dummies, three dummies capturing product market competition, a year dummy, and a dummy for foundation of the establishment after the year 1990.

\section{Results}

\subsection{Initial Estimates}

Table 2 provides the initial estimates. The table shows the results on the key explanatory variables. The other explanatory variables are included but are suppressed to save space. The full set of results can be found in Appendix Table A3.

The determinants of family-friendly and equal opportunity practices are estimated by using a multivariate probit model. ${ }^{10}$ This model is a generalization of the bivariate model (Greene 2003: 931-933). Similar to a bivariate model, the multivariate model allows for correlated error terms between the various probit equations. The estimates show that all of the fifteen correlations of the error terms are significantly positive. This suggests that unobserved factors influence the provision of the various practices in the same direction. ${ }^{11}$

The share of female employees is a significantly positive covariate of the provision of OGPs; only for leave policies, the positive coefficient on female employees is not significant. The positive association between the share of female employees and OGPs suggests that the practices are more likely to be provided if there is a higher demand for them.

Most importantly in our context, the incidence of a works council significantly increases the likelihood that each of the six policies is provided. ${ }^{12,13}$ This conforms to the hypothesis that works councils take women's interests into account and promote both workfamily balance and gender equality. They may push through OGPs against prejudiced 
employers or may promote these policies by communicating employees' preferences to management, solving commitment problems of the employer and reducing supervisor opportunism at intermediate layers of hierarchy.

The estimated influences of works councils are not only statistically significant, but also economically very meaningful. The incidence of a council increases the probability of flexible work schedules for employees with care responsibilities by 13.9 percentage points. Taking into account that 43.2 percent of the establishments provide flexible work schedules, this implies an increase in the probability of such work schedules by 32.2 percent. The marginal effects on the other family-friendly practices are 7.6 percentage points for support to employees on parental leave, 6.8 percentage points for support to employees with relatives needing care, 4.0 percentage points for support with childcare, and 3.6 percentage points for participation in a cross-company network of family-friendly firms.

Turning to equal opportunity practices, works council incidence is associated with a 2.3 percentage point higher probability that the establishment has implemented measures to promote the advancement of women. Given that 3.7 percent of the establishments have implemented such measures, this implies an increase in the probability of equal opportunity practices by 62 percent.

The other industrial relations variables also play a role in the provision of OGPs. Collective bargaining coverage and orientation at a collective bargaining contract tend to be positively associated with the provision of a series of practices. However, the positive associations are less strong than the associations the works council variable has with the OGPs. Moreover, the estimates suggest that coverage by firm-level agreement plays no significant and coverage by an industry-level agreement an even a significantly negative role in the provision of support with child care. Orientation at a collective bargaining contract is not significantly 
associated with both participation in a network of family-friendly firms and support with child care.

Alternative forms of nonunion employee representation are positively associated with each of the six OGPs. The associations are not only statistically significant, but also economically meaningful. They are roughly of the same magnitude as the associations of works councils with the OGPs. The findings show that also alternative forms of nonunion employee representation voluntarily implemented by the employer can help improve the provision of family-friendly and equal opportunity practices. One reason may be that they provide channels for improved communication and information sharing between employees and management. On the one hand, the findings might indicate that alternative forms of nonunion employee representation play a role similar to works councils in the provision of OGPs. On the other hand, it has to be taken into account that these forms are less stable (Ellguth 2009) and their creation depends on the discretion of the employer. By contrast, the implementation of a works council depends on the decision of the employees. This provides the opportunity for employees to push through work-family balance and gender equality even when employers do not implement employee representation on their own.

\subsection{Controlling for the Wage Level}

The positive link between works councils and OGPs might simply reflect an income effect. A series of studies have shown that the wage level is higher in establishments with a works council (Jirjahn 2017). Thus, if family-friendly and equal opportunity practices are normal goods, the link between works councils and OGPs might be due to the higher wage level.

In order to test this alternative explanation, we control for the wage per employee. Table 3 shows the results. As the wage variable has a larger number of missing values, sample size 
is reduced from 16,391 to 13,363 observations. For the purpose of comparison, we also present estimates with the smaller sample that do not control for the wage level. ${ }^{14}$

The wage level has a significantly positive influence on each of the six OGPs. This conforms to the notion that employees with higher incomes demand more work-family balance and equal opportunities. However, including the wage variable does not change our key results. Works council incidence remains a significant determinant of the six OGPs. Moreover, the magnitudes of the estimated influences decrease only modestly when controlling for wages. Thus, we do not find evidence that the link between works councils and organizational gender policies is simply driven by an income effect. In what follows we do no longer include the wage variable as it reduces the number of observations.

\subsection{The Issue of Endogeneity}

We recognize that our results may suffer from endogeneity of the works council variable. While the WCA provides employees the right to a works council, the decision to adopt a works council depends on various circumstances (Jirjahn and Smith 2006). There may be unobserved factors correlated with both works council incidence and OGPs. These unobserved factors could result in an omitted variable bias. From a theoretical viewpoint, this bias could result in an overestimation or underestimation of the influence of works councils.

If there were unobserved factors positively influencing both works council incidence and OGPs, the effect of works councils would be overestimated. For example, our variables may only incompletely account for the managerial environment. Supportive managers may encourage employees to adopt a works council. For example, they may encourage the adoption of a works council to signal that the establishment is a good employer (Backes-Gellner and Tuor 2010). At the same time, they may also tend to implement family-friendly and equal opportunity practices. In this case, the estimated coefficient on the works council variable 
would not only capture the works council effect, but also the positive influence of the supportive managerial environment on OGPs.

By contrast, if there were unobserved factors positively influencing the incidence of a works council and negatively influencing the provision of OGPs, the effect of works councils would be underestimated. For example, incompetent managers may be not able to build trustful relationships with the workforce so that employees are more likely to have works council to protect their interests. ${ }^{15}$ These managers may also be less likely to provide measures to promote work-family balance and gender equality. In that case, the estimated coefficient on the works council variable would not only capture the works council effect, but also the negative influence of an incompetent management on OGPs. ${ }^{16}$ Another possible scenario could be that employees are more likely to have a works council to protect their interests when the establishment faces a difficult economic situation (Jirjahn 2009, 2010). In such situation, managers may have a stronger focus on short-term profitability and do not implement measures improving employment relations and establishment performance in the long run. Thus, if there are unobserved adverse economic conditions, the estimated coefficient on the works council variable would also capture the negative influence of the adverse conditions on the use of OGPs.

We examine possible endogeneity of works council incidence by estimating a recursive multivariate probit model (Balia and Jones 2008, Jones 2007). This model is an extension of the recursive bivariate model (Greene 1998). In principle, identification of the recursive probit model is ensured by its inherent nonlinearity (Wilde 2000). However, to avoid that identification relies solely on the functional form, exclusion restrictions are usually imposed to improve identification. Finding convincing exclusion restrictions is always a matter of debate. Just-identifying exclusion restrictions are based on assumptions that cannot be formally tested (Heckman 2000, Keane 2010). They can only be justified by reasoning and an appeal to 
intuition. Hence, attempts to account for endogeneity should be largely viewed as exploratory.

Here we use the share of establishments with works councils in the industry and federal state of the respective establishment. This share is calculated for 41 detailed industries in 16 federal states. We use the share of establishments with works councils in the year 2012 to instrument works council incidence in the individual establishment in 2012 and the share of establishments with works councils in 2016 to instrument individual works council incidence in 2016. ${ }^{17}$ The share of establishments with works councils reflects the general propensity within a region and narrowly defined industry that works councils are present. Hence, it should have a positive influence on the individual establishment's probability of having a works council.

The validity of the instrument requires that the share of establishments with works councils in the industry and region has no direct effect on the OGPs of the individual establishment, but influences OGPs only indirectly through the incidence of a works council in that establishment. Of course, one could imagine that the share of establishments with a works council might reflect industry-specific working conditions that are also present in the individual establishment. This might suggest a direct link between the instrument and the individual establishment's OGPs. However, to the extent that our dataset allows to control for relevant working conditions at the establishment level, there should be no direct effect of the instrument. ${ }^{18}$ We control among others for innovations, vintage of technology, establishment age, shift work, overtime, weekly hours, establishment size, gender composition of the workforce, part-time, temporary contracts, skills, apprenticeship, collective bargaining and type of ownership. Moreover, note that our instrument allows us to still include the 12 broadly defined industry dummies and the 15 federal state dummies in the regressions. Our control variables should capture important aspects of the working conditions within the establishment increasing our confidence in the validity of the instrument. The basic point is that an instrument 
may be not valid per se, but can be valid only after conditioning on covariates (Angrist and Pischke 2009: chapter 4.5.2). Thus, to the extent that we control for critical establishment characteristics, we do not expect a direct effect of the share of establishments with a works council. We assume that this share influences OGPs only indirectly through the incidence of a works council, but not directly and independently of the incidence of the works council.

Table 4 provides the key results. The determinants of family-friendly and equal opportunity practices are jointly estimated with the determinants of works council incidence. The estimates show that our identifying variable is significantly associated with works council incidence. The share of establishments with works councils in the industry and region is a positive determinant of the individual establishment's probability of having a works council.

The error term of the works council equation is significantly correlated with the error terms of the equations for the family-friendly and equal opportunity practices. Thus, the hypothesis of exogeneity is rejected and the works council variable has to be considered as endogenous. The correlations between the error term of the works council equation and the error terms of the other equations are negative. This suggests that there are unobserved factors positively influencing the incidence of a council and negatively influencing the provision of OGPs. As discussed, incompetent managers or adverse economic conditions may contribute to distrust and adversarial employment relations inducing employees to implement a works council. At the same time, these factors are associated with a low propensity to promote workfamily balance and equality.

The negative correlation between the error terms implies that the estimated effect of works councils on OGPs is stronger in the recursive model than the in the simple multivariate probit of Table 2. ${ }^{19}$ The marginal effect on measures to promote the advancement of women is now 3.4 percentage points. The marginal effects on the family-friendly practices are 18.4 percentage points for flexible work schedules, 9.5 percentage points for support to employees 
on parental leave, 10.0 percentage points for support to employees with relatives needing care, 6.4 percentage points for support with childcare, and 5.6 percentage points for participation in a cross-company network of family-friendly firms.

Altogether, even when taking the endogeneity of works council incidence into account, the estimates confirm our key finding of a positive influence of works councils on familyfriendly and equal opportunity practices. Endogeneity implies that the positive effect of works councils on the provision of these practices is underestimated in the simple multivariate probit regression.

As a check of robustness, we add up the policies listed in Table 1 and use the number of OGPs as the dependent variable. Table A8 provides the results of a two-step instrumental variables regression. In this regression, identification is solely ensured through the exclusion restriction, but not through distributional assumptions. In the first step, the determinants of works council incidence are estimated by a linear probability model. This approach confirms that the share of establishments with works councils in the industry and region is a positive determinant of the individual establishment's probability of having a works council. In the second step, the predicted value of council incidence is included in the regression explaining the number of OGPs. This step shows a positive influence of works councils on the number of OGPs.

In Table A9, we return to the recursive multivariate probit and examine if our results are influenced by alternative definitions of the instrument. So far, we have used the share of establishments with works councils in the current year as an instrument for the individual establishment's propensity of having a works council. Regression (1) shows that we obtain similar results when alternatively using a three-year lag of the instrument (the share in 2009 as instrument for works council incidence in 2012 and the share in 2013 as instrument for works council incidence in 2016). 
So far, we have used the share of establishments with works councils within an industry and region as instrument. Despite the many controls included in the regression, we cannot completely rule out the possibility that the instrument might partially capture unobserved industry-specific factors directly influencing the provision of OGPs. In order to address this issue, we use only the share of works councils within a region (without differentiating by industry) as an alternative instrument. In a similar vein, we also use only the share within an industry (without differentiating by region) as a further alternative instrument to rule out the possibility that the instrument captures direct region-specific factors. As shown by regressions (2) and (3), our key results are confirmed when using the alternative definitions of the instrument.

\subsection{Separate Estimates by Collective Bargaining Status}

As emphasized in the theoretical background discussion, the functioning of works councils may depend on the moderating role of collective bargaining coverage. In order to examine this moderating role, Table 5 provides separate recursive multivariate probit estimates by collective bargaining status. For establishments not formally bound to collective bargaining agreements and establishments covered by firm-level agreements, we obtain a significant influence of works councils only on the propensity to participate in a cross-company network of familyfriendly firms. ${ }^{20}$ By contrast, for establishments covered by industry-level agreements, the estimates show a significant influence on all of the OGPs, namely measures to promote the advancement of women, support with childcare, flexible work schedules, support to employees with relatives needing care, support to employees on parental leave, and participation in crosscompany network of family-friendly firms. These results conform to the hypothesis that works councils are more effective in shaping the personnel policy of establishments when 
distributional conflicts are settled outside the establishment by unions and employers' associations.

Interestingly, we find significantly negative correlations between the error term in the works council equation and the error terms in the equations for the OGPs also only for establishments covered by industry-level agreements. For uncovered establishments and establishments covered by firm-level agreements, most of the corresponding correlations are positive, but statistically insignificant. Thus, we find clear evidence for the endogeneity of works council incidence only for establishments covered by industry-level agreements. One possible explanation for the endogeneity of works councils and the negative correlations of error terms in the industrial relations regime with industry-level agreements could be that reducing basic distributional conflicts at the establishment level not only increases the effectiveness of works councils, but also makes it easier for employees to adopt a works council even in challenging situations.

\subsection{Further Estimates}

Industry might also moderate the effects of works councils. Thus, we also performed separate estimates for the manufacturing and the service sector. As shown in Table A10, works council incidence has a significantly positive influence on each of the OGPs in the manufacturing sector. Works council incidence is also a significant determinant of the provision of the various OGPs in the service sector except help with child care. Considering marginal effects, the magnitude of the influence of works councils appears to be somewhat stronger in the manufacturing than in the service sector. This might reflect that industrial relations in the manufacturing sector are the institutional benchmark. The dual system of employee representation with establishment-level codetermination and industry-level collective bargaining is more common in the manufacturing sector. However, the basic point remains that 
we find a positive influence of works councils on OGPs in both the manufacturing and the service sector.

Our initial estimates in Table 3 suggest that alternative forms of nonunion employee representation are also positively associated with OGPs. This gives rise to the question of whether these alternative forms are substitutes to works councils. To address this question we run separate estimates for establishments with and without alternative forms of nonunion employee representation. Table A11 shows the results. Works council incidence has a significant influence on help with child care and on support for employees with relatives needing care only in establishments without, but not in establishments with alternative forms of employee representation. This may indicate a substitutive relationship between works councils and alternative employee representation. However, with respect to the other four OGPs, the estimates show a significant influence of works councils for both types of establishments. Moreover considering the marginal effects on the various OGPs, the influence of works councils is sometimes stronger in establishments with and sometimes stronger in establishments without alternative employee representation. Altogether, our estimates do not support the view that works councils and alternative forms of nonunion employee representation are generally substitutive.

Finally, we estimate a recursive model accounting for the possibility that not only works councils, but also alternative forms of employee representation may be endogenous. In Table A12, we instrument both the incidence of a works council and the incidence of alternative employee representation. The latter is instrumented by the share of establishments with alternative employee representation calculated for 41 detailed industries in 16 federal states. The estimates suggest that alternative employee representation is endogenous with respect to three OGPs, namely help with child care, support for employees with relatives needing care, and support for employees on parental leave. However most importantly, also this exercise 
confirms that both works councils and alternative forms of nonunion employee representation have a significantly positive influence on each of the six OGPs. Again, we emphasize that this does not necessarily imply that alternative forms of employee representation play the same role as works councils. While the adoption of alternative employee representation depends on the discretion of the employer, the implementation of a works council depends on the decision of the employees. Thus, a-works councils provides the opportunity for employees to negotiate family-friendly and equal opportunity practices even when the employer does not voluntarily implement employee representation.

\section{Conclusions}

Our analysis provides German evidence that establishments are more likely to provide familyfriendly and equal opportunity practices when a works council is present. The key pattern of results also holds when taking the endogeneity of works councils into account. The estimated influence of works councils is even stronger when endogeneity is accounted for. However, our estimates also show that the influence of works councils on OGPs is heterogeneous. Performing separate estimate by collective bargaining status, we find a significant influence of works councils on the various OGPs only for establishments covered industry-level collective bargaining agreements, but not for uncovered establishments or establishments with firm-level agreements. This pattern of results fits previous studies showing that works councils are more effective in shaping the personnel policy of establishments when basic distributional conflicts are settled outside the establishments by unions and employers' associations.

Our findings also shed some light on the question of whose interests works councils take into account. If works councils took primarily the interests of men into account, we would have found a rather limited influence on OGPs. We would have found an influence only on practices such as flexible work schedules that also benefit men. In contrast, our results provide 
evidence that works councils are positively associated with a broad range of OGPs. Works councils also have an influence on practices such as equal opportunity practices which primarily benefit women. This indicates that works councils take women's interest into account. They may push through the gender policies against prejudiced employers or may promote these policies by mitigating organizational failures through information sharing and overcoming employers' commitment problems.

We end this article with suggestions for future research. A question often arising in social sciences is whether there are alternative interpretations of empirical findings. One alternative explanation for the positive influence of works councils on the various OGPs might be that works councils simply formalize the personnel policy of establishments without having a specific focus on women's interests. ${ }^{21}$ Thus, future research should continue examining to what extent works councils indeed take women's interests into account.

Moreover, it would be interesting to extend our analysis to other countries where works councils are present. This would allow to examine the generalizability of our results. First, our finding on the moderating role of industry-level collective bargaining suggests that the functioning of works councils depends on the broader industrial relations system. Thus, additional insights could be obtained by examining works councils in countries with different institutional frameworks. Second, the participation rights of works councils differ between countries. For example, works councils also have strong participation rights in the Netherlands (van den Berg et al. 2011a, 2011b) while their rights are less strong in France (Fairris and Askenazy 2010) and Belgium (van den Berg et al. 2017). Examining the link between works councils and OGPs in different countries could give an answer to the question of how strong worker representation needs to be in order to be effective. Our estimates suggest that alternative forms of worker representation also have a positive influence on the provision of OGPs. This might indicate that even weak worker representation could be effective in fostering OGPs. 
However, more research is certainly warranted to examine this issue in more detail. Comparing countries with weak and strong works councils would be a fruitful way to conduct such research.

Finally, now that the role of works councils on the provision of family-friendly and equal opportunity practices has been examined, it would be interesting to analyze if works councils also have an influence on the outcomes of these practices for the economic performance of establishments and the well-being of employees. For Germany, there is evidence that family-friendly and equal opportunity practices can be indeed effective (Huffman et al. 2017, Lauber and Storck 2019). This gives rise to the question of whether the outcomes of the practices depends on the presence of a works council. 


\section{References}

Aghion, P. and B. Hermalin. 1990. "Legal Restrictions on Private Contracts Can Enhance Efficiency," Journal of Law, Economics and Organization 6: 381 - 409.

Akerlof G. and R. Kranton. 2000. "Economics and Identity," Quarterly Journal of Economics 115: 715 -753 .

Albrecht, J., P. Edin, M. Sundstrom and S. Vroman. 1999. "Career Interruptions and Subsequent Earnings: A Reexamination Using Swedish Data," Journal of Human Resources 34: 294 - 311.

Angrist, J.D. and J.S. Pischke. 2009. Mostly Harmless Econometrics. Princeton University Press. Princeton and Oxford.

Arlulampalam, W., A. Booth and M. Bryan. 2007. "Is There a Glass Ceiling over Europe: Exploring the Gender Pay Gap across the Wage Distribution," Industrial and Labor Relations Review 60: $163-186$.

Askildsen, J., U. Jirjahn and S.C. Smith. 2006. "Works Councils and Environmental Investment: Theory and Evidence from German Panel Data," Journal of Economic Behavior and Organization 60: $346-372$.

Backes-Gellner, U. and S.N. Tuor. 2010. "Avoiding Labor Shortages by Employer Signaling - On the Importance of Good Work Climate and Labor Relations," Industrial and Labor Relations Review 63: $271-86$.

Balia, S., and A. Jones. 2008. "Mortality, Lifestyle and Socio-economic Status," Journal of Health Economics 27: $1-26$.

Bardoel, E.A., S.A. Moss, K. Smyrnios and P. Tharenou. 1999. "Employee Characteristics Associated with the Provision of Work-Family Policies and Programs," International Journal of Manpower 20: $563-576$.

Becker, G. 1957. The Economics of Discrimination, Chicago, University of Chicago Press.

Bertrand, M. 2011. "New Perspectives on Gender," in Handbook of Labor Economics, Vol. 4B, edited by D. Card and O. Ashenfelter, Amsterdam, Elsevier: 1543 - 1590.

Bertrand, M., D. Chugh and S. Mullainathan. 2005. "Implicit Discrimination," American Economic Review 95: $94-98$.

Bilanakos, C., J.S. Heywood, J. Sessions and N. Theodropoulous. 2018. "Does Delegation Increase Training?" Economic Inquiry 56: 1089 - 1115.

Black B., M. Trainor and J. Spencer. 1999. "Wage Protection Systems, Segregation, and Gender Pay Inequalities: West Germany, the Netherlands and Great Britain," Cambridge Journal of Economics 23: 449 - 464.

Blau, F. and L. Kahn. 2003. "Understanding International Differences in the Gender Pay Gap," Journal of Labor Economics 21: 106 - 144.

Blau, F. and L. Kahn. 2017. "The Gender Wage Gap: Extent, Trends, and Sources," Journal of Economic Literature 55: 789 - 865. 
Bowles H., L. Babock and L. Lai. 2007. "Social Incentives for Sex Differences in the Propensity to Initiate Negotiation: Sometimes It Does Not Hurt to Ask," Organizational Behavior and Human Decision Processes 103: 84 - 103.

Brookes M., T. Hinks and D. Watson. 2001. "Comparison in Gender Wage Differentials and Discrimination between Germany and the United Kingdom," Labour 15: 393 - 414.

Budd, J.W. and K.A. Mumford. 2004. "Trade Unions and Family-Friendly Policies in Britain," Industrial and Labor Relations Review 57: 204 - 222.

Budd, J.W. and K.A. Mumford. 2006. "Family-Friendly Work Practices in Britain: Availability and Perceived Accessibility," Human Resource Management 45: 23 - 42.

Burgess, S. and P. Metcalfe. 2000. "The Use of Incentive Schemes in the Public and the Private Sectors: Evidence from British Establishments," CMPO Working Paper No. 00/15.

Burgess, S. and M. Ratto. 2003. "The Role of Incentives in the Public Sector: Issues and Evidence," Oxford Review of Economic Policy 19: 285 - 300.

Campaner, A., J.S. Heywood and U. Jirjahn. 2018. "Flexible Work Organization and Employer Provided Training: Evidence from German Linked Employer-Employee Data," IZA Discussion Paper No. 11696, Bonn.

Capellari, L. and S. Jenkins. 2003. "Multivariate Probit Regression Using Simulated Maximum Likelihood," STATA Journal 3: 278 - 294.

Castilla E. 2008. "Gender, Race, and Meritocracy in Organizational Careers," American Journal of Sociology 113: 1479 - 1526.

Castilla E. and S. Bernard. 2010. "The Paradox of Meritocracy in Organizations," Administrative Science Quarterly 55: 543 - 576.

Cebrìan, I. and G. Moreno. 2015. "The Effects of Gender Differences in Career Interruptions on the Gender Wage Gap in Spain," Feminist Economics 21: 1 - 27.

Christofides, L., A. Polycaropou and K. Vrachimis. 2013. "Gender Wage Gaps, 'Sticky Floors' and 'Galss Ceilings' in Europe," Labour Economics 21: 86 - 102.

Cockburn, C. 1989. "Equal Opportunities: The Short and Long Agenda," Industrial Relations Journal 20: $213-225$.

Cornelissen, T. J.S. Heywood and U. Jirjahn. 2011. "Performance Pay, Risk Attitudes and Job Satisfaction," Labour Economics 18: 229 - 239.

Coverman, S. and J. Sheley. 1986. "Change in Men's Housework and Child-Care Time, 1965-1975," Journal of Marriage and the Family 48: 413 - 422.

Cunnison, S. and J. Stageman. 1995. Feminising the Unions: Challenging the Culture of Masculinity. Aldershot: Avebury.

Deitch, C.H., and M.L Huffman. 2001. "Family Responsive Benefits and the Two-Tiered Labor Market," in R. Hertz and N.L. Marshall, eds., Working Families: The Transformation of the American Home. Berkely: University of California Press, 103 - 130. 
Dickens, L. 2000. "Collective Bargaining and the Promotion of Gender Equality at Work: Opportunities and Challenges for Trade Unions," Transfer 6: 193 - 208.

Doucouliagos, H., R. Freeman and P. Laroche. 2017. The Economics of Trade Unions: A Study of a Research Field and Its Findings. Routlegde, New York, NY.

Eaton, S. 2003. "If You Can Use Them: Flexibility Policies, Organizational Commitment, and Perceived Performance," Industrial Relations 42: 154 - 167.

Ellguth, P. 2009. "Betriebsspezifische Formen der Mitarbeitervertretung - welche Betriebe, welche personalpolitischen Wirkungen?" Industrielle Beziehungen 16: 109 - 135.

Ellguth, P., S. Kohaut and I. Möller. 2014. "The IAB Establishment Panel - Methodological Essentials and Data Quality," Journal for Labour Market Research 47: 27 - 41.

European Commission. 2009. Gender Segregation in the Labour Market. Luxembourg.

European Commission. 2016. Strategic Engagement for Gender Equality 2016-2019. Luxembourg.

European Foundation for the Improvement of Living and Working Conditions. 2013. Women, Men and Working Conditions in Europe: A Report Based on the Fifth European Working Conditions Survey. Dublin.

Fairris, D. and P. Askenazy. 2010. "Works Councils and Firm Productivity in France," Journal of Labor Research 31: $209-229$.

Fakik, A. 2014. "Availability of Family-Friendly Work Practices and Implicit Wage Costs: New Evidence from Canada," IZA Discussion Paper No. 8190, Bonn.

Fitzenberger, B. and G. Muehler. 2015. "Dips and Floors in Workplace Training: Using Personnel Records to Estimate Gender Differences," Scottish Journal of Political Economy 62: 325-429.

FitzRoy, F. and K. Kraft. 1987. "Efficiency and Internal Organization - Works Councils in West German Firms," Economica 54: 493 - 504.

Flüter-Hoffmann, C. 2005. "Familienfreundliche Regelungen in Tarifverträgen und Betriebsvereinbarungen: Beispiele guter Praxis," Bundesministerium für Familie, Senioren, Frauen und Jugend, Berlin.

Freeman, R. 1976. "Individual Mobility and Union Voice in the Labor Market," American Economic Review 66: $361-377$.

Freeman, R. and E. Lazear. 1995. "An Economic Analysis of Works Councils," in Works Councils Consultation, Representation and Cooperation in Industrial Relations, edited by Joel Rogers and Wolfgang Streeck, Chicago: University of Chicago Press: 27 - 52.

Freeman, R. and J. Medoff. 1979. "The Two Faces of Unionism,” The Public Interest 57: 69 - 93.

Gartner H. and G. Stephan. 2004. "How Collective Contracts and Works Councils Reduce the Gender Wage Gap,” Nuremberg, IAB Discussion Paper No. 07.

Glass, J. and T. Fujimoto. 1995. "Employer Characteristics and the Provision of Family Responsive Policies," Work and Occupations 22: $380-411$. 
Greene, W.H. 1998. "Gender Economics Courses in Liberal Arts Colleges: Further Results," Journal of Economic Education 29: 291 - 300.

Greene, W.H. 2003. Econometric Analysis, Fifth edition, New-Jersey, Prentice-Hall.

Grundert, S. and K.U. Mayer. 2012. "Gender Segregation of Training and Social Mobility of Women in West Germany," European Sociological Review 28: 59 - 81.

Goldin, C. 2014a. "A Grand Gender Convergence: Its Last Chapter," American Economic Review 104: $1-30$.

Goldin, C. 2014b. "A Pollution Theory of Discrimination: Male and Female Differences in Occupations and Earnings," in L. Boustan, C. Frydman and R. Margo, eds,, Human Capital and History: The American Record, Chicago, University of Chicago Press: 313 - 348.

Goldin, C. and C. Rouse. 2000. "The Impact of 'Blind' Auditions on Female Musicians," American Economic Review 90: 715 - 721.

Heckman, J. 2000. "Causal Parameters and Policy Analysis in Economics: A Twentieth Century Retrospective," Quarterly Journal of Economics 115: 45 - 97.

Heery, E. 2006. “Equality Bargaining: Where, Who, Why?” Gender, Work and Organization 13: 522 -542 .

Heinze A. and E. Wolf. 2010. "The Intra-firm Wage Gap: A New View on Wage Differentials Based on Linked Employer-Employee Data," Journal of Population Economics 23: 851 - 879.

Heywood, J.S. and U. Jirjahn. 2002. "Payment Schemes and Gender in Germany," Industrial and Labor Relations Review 56: 44 - 64.

Heywood, J.S. and U. Jirjahn. 2009. "Family Friendly Practices and Worker Representation: German Evidence," Industrial Relations 48: 121 - 145.

Heywood, J.S., W.S. Siebert and X. Wei. 2007. "The Implicit Wage Cost of Family Friendly Work Practices," Oxford Economic Papers 59: 275 - 300.

Hinz, T. and J. Mohrenweiser. 2019. "Competition, Institutions and Company-sponsored Training," Economics of Education Working Paper Series 162, University of Zürich.

Holst, E. and A. Busch. 2008. "The Gender Pay Gap in Germany: How Large Is It? Is It Decreasing? How Much Is Due to Workplace Discrimination?" In: Heady B. and Holst E., eds., A Quarter Century of Change, Berlin: $81-86$.

Hübler, O. 2005. "Is There a Varying Unexplained Gender Wage Gap in Germany?" Applied Economics Quarterly 51: $29-48$.

Hübler, O. and U. Jirjahn. 2003. "Works Councils and Collective Bargaining in Germany: The Impact on Productivity and Wages," Scottish Journal of Political Economy 50: 1 - 21.

Huffman, M.L., J. King and M. Reichelt. 2017. "Equality for Whom: Organizational Policies and the Gender Gap across the German Earnings Distribution," Industrial and Labor Relations Review 70: $16-41$.

Janssen, S., S. Tuor Sartore and U. Backes-Gellner. 2016. "Discriminatory Social Attitudes and Varying Gender Pay Gaps within Firms" Industrial and Labor Relations Review 69: 253 - 279. 
Jirjahn, U. 1998. Effizienzwirkungen von Erfolgsbeteiligung und Partizipation - Eine mikroökonomische Analyse. Campus: Frankfurt a.M.

Jirjahn, U. 2008. "On the Determinants of Shift Work and Overtime Work: Evidence from German Establishment Data," British Journal of Industrial Relations 46: 133 - 168.

Jirjahn, U. 2009. "The Introduction of Works Councils in German Establishments: Rent Seeking or Rent Protection?" British Journal of Industrial Relations 47: 521 - 545.

Jirjahn, U. 2010. "Works Councils and Employment Growth in German Establishments," Cambridge Journal of Economics 34: 475 - 500.

Jirjahn, U. 2011. "Gender, Worker Representation and the Profitability of Firms in Germany," European Journal of Comparative Economics 8: 281 - 298.

Jirjahn, U. 2017. "Works Councils and Collective Bargaining in Germany: A Simple Theoretical Extension to Reconcile Conflicting Empirical Findings," Journal of Institutional and Theoretical Economics 173: 322 - 346.

Jirjahn, U. 2018. "Works Councils and Employer Attitudes toward the Incentive Effects of HRM Practices," Journal of Participation and Employee Ownership 1: 98 - 127.

Jirjahn, U. and K. Kraft. 2007. "Intra-Firm Wage Dispersion and Firm Performance - Is There a Uniform Relationship?” Kyklos 60: 231 - 253.

Jirjahn, U. and J. Mohrenweiser 2016. "Owner-Managers and the Failure of Newly Adopted Works Councils," British Journal of Industrial Relations 54: 815 - 845.

Jirjahn, U. and J. Mohrenweiser. 2019. "Works Councils and Organizational Gender Policies in Germany," IZA Discussion Paper No. 12344, Bonn.

Jirjahn, U. and S. Müller. 2014. "Nonunion Worker Representation, Foreign Owners and Firm Performance," Oxford Economic Papers 66: 140 - 163.

Jirjahn, U. and S.C. Smith. 2006. "What Factors Lead to Management to Support or Oppose Employee Participation - with and without Works Councils? Hypotheses and Evidence from Germany," Industrial Relations 45: 650 - 680.

Jirjahn, U. and S.C. Smith. 2018. "Nonunion Employee Representation: Theory and the German Experience with Mandated Works Councils," Annals of Public and Cooperative Economics 89: $201-234$.

Jirjahn U. and G. Stephan. 2004. "Gender, Piece Rates and Wages: Evidence from Matched EmployerEmployee Data," Cambridge Journal of Economics 28: 683 - 704.

Jones, A. 2007. Applied Econometrics for Health Economists: A Practical Guide. Oxford: Radcliffe Medical Publishing.

Kassouf A. and R. Hoffman. 2006. "Work-Related Injuries Involving Children and Adolescents: Application of a Recursive Bivariate Probit Model," Brazilian Review of Econometrics 26: 105 126. 
Kaufman, B. and D. Levine. 2000. "An Economic Analysis of Employee Representation," in Nonunion Employee Representation: History, Contemporary Practice, and Policy, edited by Bruce E. Kaufman and David I. Levine, New York: M.E. Sharpe: 149 - 175.

Keane, M. 2010. "Structural vs. Atheoretical Approaches to Econometrics," Journal of Econometrics 156: $3-20$.

Kirsch, A. and S. Blaschke. 2014. "Women's Quotas and Their Effects: A Comparison of Austrian and German Trade Unions,” European Journal of Industrial Relations 20: 201 - 217.

Kohaut, S. and I. Möller. 2017. "Führungspositionen in Betrieben und Verwaltungen: Oberste Chefetage bleibt Männerdomäne," IAB Kurzbericht 27/2017, Nuremberg.

Kriechel, B., S. Muehlemann, H. Pfeifer and M. Schuette. 2014. "Works Councils, Collective Bargaining and Apprenticeship Training," Industrial Relations 53: 199 - 222.

Lauber, V. and J. Storck. 2019. "Helping with the Kids? How Family-Friendly Workplaces Affect Parental Wellbeing and Behavior?" Oxford Economic Papers 71: 95 - 118.

Lee, S. 2004. "A Re-examination of Public Sector Wage Differentials in the United States: Evidence from the NLSY with Geocode," Industrial Relations 43: 448 - 472.

Levine, D. 1991. "Cohesiveness, Productivity and Wage Dispersion," Journal of Economic Behavior and Organization 15: $237-255$.

Lindbeck, A. and D. Snower. 2001. "Centralized Bargaining and Reorganized Work: Are They Compatible?" European Economic Review 45: 1851 - 1875.

Machin, S. and S. Wadhwani. 1991. "The Effects of Unions on Organizational Change and Employment," Economic Journal 101: 835 - 854.

Müller, S. 2011. "Works Councils and Firm Profits Revisited," British Journal of Industrial Relations 49: $\mathrm{s} 27-\mathrm{s} 43$.

Müller, S. 2012. "Works Councils and Establishment Productivity," Industrial and Labor Relations Review 65: $880-898$.

OECD. 2003. Employment Outlook, Paris, OECD Publishing.

Osterman, P. 1995. "Work/Family Programs and the Employment Relationship," Administrative Science Quarterly 40: 681 - 700.

Park, T.Y., E.S. Lee and J.W. Budd. 2019. "What Do Unions Do for Mothers? Paid Maternity Leave Use and the Multifaceted Roles of Labor Unions," Industrial and Labor Relations Review 72: $662-692$.

Perotin, V., A. Robinson and J. Loundes. 2003. "Equal Opportunities Practices and Enterprise Performance: An Investigation on Australian and British Data," Working Paper No. 14 of the InFocus Programme on Promoting the Declaration on Fundamental Principles and Rights at Work, ILO: Geneva.

Peus, C. 2006. "Work-Family Balance? The Case of Germany," MIT Workplace Center, Sloan School of Management, Working Paper No. 0025. 
Pfeifer, C. 2011. "Works Councils, Union Bargaining, and Quits in German Firms," Economic and Industrial Democracy 32: 243 - 260.

Ross, C. and J. Mirowksy. 1988. "Child Care and Emotional Adjustment to Wives' Employment," Journal of Health and Social Behavior 29: 127 - 138.

Rudman, L. 1998. "Self-Promotion as a Risk Factor for Women: The Costs and Benefits of Counterstereotypical Impression Management," Journal of Personality and Social Psychology 74: $629-645$.

Rudman L. and K. Fairchild. 2004. "Reactions to Counterstereotypic Behavior: The Role of Backlash in Cultural Stereotype Maintenance," Journal of Personality and Social Psychology 87: 157 176.

Smith, Stephen C. 1991. "On the Economic Rationale for Codetermination Law," Journal of Economic Behavior and Organization 16: 261 - 281.

Smith, S.C. 2006. "Employee Participation Rights in Corporate Governance: Economic Rationale, a Test of a Leading Theory, and Some Modest Policy Proposals," in Advances in the Economic Analysis of Participatory and Labor Managed Firms, edited by P. Kalmi and M. Klinedinst, Amsterdam, Elsevier: 105 - 146.

Smith, N., Valdemar and M. Verner. 2013. "Why Are So Few Females Promoted into CEO and Vice President Positions? Danish Empirical Evidence, 197-2007," Industrial and Labor Relations Review 63: $380-408$.

Stettes, O. 2008. "Betriebsräte und alternative Formen der Mitbestimmung - Ergebnisse IW-Zukunftspanel," IW Trends 3/2008, Institut der deutschen Wirtschaft, Köln.

United Nations Human Rights Council. 2011. Gender Equality Policy. Geneva.

United Nations Office at Geneva. 2016. Policy for Gender Equality and the Empowerment of Women: 2016-2020. Geneva.

Van den Berg, A., Y. Grift and A. van Witteloostuijn. 2011a. "Managerial Perceptions of Works Councils' Effectiveness in the Netherlands," Industrial Relations 50: 497 - 513.

Van den Berg, A., Y. Grift and A. van Witteloostuijn. 2011b. "Works Councils and Organizational Performance: The Role of Top Managers' and Works Councils' Attitudes in Bad vis-à-vis Good Times," Journal of Labor Research 32: 136 - 156.

Van den Berg, A., A. van Witteloostuijn and O. Van der Brempt. 2017. "Employee Workplace Representation in Belgium: Effects on Firm Performance," International Journal of Manpower 38: $130-144$.

Wilde, J. 2000. "Identification of Multiple Probit Models with Endogenous Dummy Regressors," Economics Letters 69: 309 - 312.

Winship, C. and L. Radbil. 1994. "Sampling Weights and Regression Analysis," Sociological Methods and Research 23: $230-257$.

Woessmann, L. and M. West. 2006. "Class Size Effects in School Systems around the World: Evidence from Between-Grade Variation in TIMMS," European Economic Review 50: 695 - 736.

World Bank. 2012. World Development Report 2012: Gender Equality and Development. Washington. 
Zwick, T. 2004. "Weiterbildungsintensität und betriebliche Produktivität," Zeitschrift für Betriebswirtschaft 74: $651-668$.

Zwick, T. 2008. "Works Councils and the Productivity Effects of Different Continuing Training Measures," Zeitschrift für Betriebswirtschaft 78 (Special Issue 1): 137 - 149. 
Table 1: Definitions and Descriptive Statistics of Key Variables

\begin{tabular}{|c|c|}
\hline Variable & Definition (Mean, Standard Deviation) \\
\hline Advancement & $\begin{array}{l}\text { Dummy equals } 1 \text { if the establishment has implemented measures to promote the } \\
\text { advancement of women; e.g., mentoring programs, specific training of female employees, } \\
\text { action plans for women, plans to increase the share of female employees }(0.037,0.189) \text {. }\end{array}$ \\
\hline Child care & $\begin{array}{l}\text { Dummy equals } 1 \text { if the establishment provides support with child care; e.g., on-site child } \\
\text { care, cooperation with child care facilities, financial contributions towards child care }(0.138, \\
0.345) \text {. }\end{array}$ \\
\hline Flexibility & $\begin{array}{l}\text { Dummy equals } 1 \text { if the establishment provides flexible work schedules for employees with } \\
\text { care responsibilities; e.g., flextime, working time accounts, telecommuting, home office } \\
(0.432,0.495) \text {. }\end{array}$ \\
\hline Relatives & $\begin{array}{l}\text { Dummy equals } 1 \text { if the establishment provides support to employees who have relatives } \\
\text { needing care; e.g., cooperation with care homes, information provision, advisory services } \\
(0.087,0.282) \text {. }\end{array}$ \\
\hline Leave & $\begin{array}{l}\text { Dummy equals } 1 \text { if the establishment provides support to employees who are on parental } \\
\text { leave; e.g., training }(0.172,0.377) \text {. }\end{array}$ \\
\hline Network & $\begin{array}{l}\text { Dummy equals } 1 \text { if the establishment participates in a cross-company network of family- } \\
\text { friendly firms }(0.030,0.171) \text {. }\end{array}$ \\
\hline Works council & Dummy equals 1 if the establishment has a works council $(0.245,0.430)$ \\
\hline Industry-level bargaining & $\begin{array}{l}\text { Dummy equals } 1 \text { if the establishment is covered by an industry-level collective bargaining } \\
\text { agreement }(0.331,0.470)\end{array}$ \\
\hline Firm-level bargaining & $\begin{array}{l}\text { Dummy equals } 1 \text { if the establishment is covered by a firm-level collective bargaining } \\
\text { agreement }(0.062,0.242)\end{array}$ \\
\hline $\begin{array}{l}\text { Orientation at collective } \\
\text { bargaining }\end{array}$ & $\begin{array}{l}\text { Dummy equals } 1 \text { if the establishment is not formally bound to collective bargaining, but } \\
\text { pursues an orientation at a collective bargaining agreement }(0.297 ; 0.457)\end{array}$ \\
\hline Alternative representation & $\begin{array}{l}\text { Dummy equals } 1 \text { if the establishment has implemented alternative forms of employee } \\
\text { representation such as staff spokesmen or round tables }(0.130,0.336)\end{array}$ \\
\hline Women & Share of the workforce that is female $(0.388,0.289)$ \\
\hline Works council share & $\begin{array}{l}\text { Share of establishments with a works council calculated for } 41 \text { industrial groups in } 16 \text { federal } \\
\text { states }(0.260,0.202) \text {. }\end{array}$ \\
\hline Wage level & Total monthly wage bill per employee divided by $1000(2.092,1.134)$ \\
\hline
\end{tabular}


Table 2: Initial Estimates

\begin{tabular}{|c|c|c|c|c|c|c|}
\hline & Advancement & Child care & Flexibility & Relatives & Leave & Network \\
\hline Works council & $\begin{array}{c}0.306 \\
{[0.023]} \\
(5.49)^{* * *}\end{array}$ & $\begin{array}{c}0.196 \\
{[0.040]} \\
(4.79)^{* * *}\end{array}$ & $\begin{array}{c}0.408 \\
{[0.139]} \\
(11.64)^{* * *}\end{array}$ & $\begin{array}{c}0.444 \\
{[0.068]} \\
(10.39) * * *\end{array}$ & $\begin{array}{c}0.319 \\
{[0.076]} \\
(8.74)^{* * *}\end{array}$ & $\begin{array}{c}0.589 \\
{[0.036]} \\
(9.93)^{* * *}\end{array}$ \\
\hline $\begin{array}{l}\text { Industry-level } \\
\text { bargaining }\end{array}$ & $\begin{array}{c}0.289 \\
{[0.021]} \\
(4.45)^{* * *}\end{array}$ & $\begin{array}{l}-0.120 \\
{[-0.023]} \\
(2.97)^{* * *}\end{array}$ & $\begin{array}{l}0.078 \\
{[0.025]} \\
(2.45)^{* *}\end{array}$ & $\begin{array}{l}0.095 \\
{[0.013]} \\
(2.07)^{* *}\end{array}$ & $\begin{array}{c}0.207 \\
{[0.047]} \\
(5.52)^{* * *}\end{array}$ & $\begin{array}{c}0.164 \\
{[0.009]} \\
(2.36) * *\end{array}$ \\
\hline Firm-level bargaining & $\begin{array}{c}0.321 \\
{[0.027]} \\
(3.81)^{* * *}\end{array}$ & $\begin{array}{c}-0.083 \\
{[-0.016]} \\
(1.36)\end{array}$ & $\begin{array}{l}0.115 \\
{[0.038]} \\
(2.22)^{* *}\end{array}$ & $\begin{array}{c}0.166 \\
{[0.024]} \\
(2.60) * * *\end{array}$ & $\begin{array}{c}0.187 \\
{[0.044]} \\
(3.38)^{* * *}\end{array}$ & $\begin{array}{c}0.244 \\
{[0.016]} \\
(2.67) * * *\end{array}$ \\
\hline $\begin{array}{l}\text { Orientation at } \\
\text { collective bargaining }\end{array}$ & $\begin{array}{c}0.190 \\
{[0.014]} \\
(3.08)^{* * *}\end{array}$ & $\begin{array}{c}-0.035 \\
{[-0.007]} \\
(1.00)\end{array}$ & $\begin{array}{l}0.155 \\
{[0.051]} \\
(5.43)^{* * *}\end{array}$ & $\begin{array}{c}0.081 \\
{[0.011]} \\
(1.88)^{*}\end{array}$ & $\begin{array}{c}0.190 \\
{[0.043]} \\
(5.54)^{* * *}\end{array}$ & $\begin{array}{c}0.106 \\
{[0.006]} \\
(1.48) \\
\end{array}$ \\
\hline $\begin{array}{l}\text { Alternative } \\
\text { representation }\end{array}$ & $\begin{array}{c}0.308 \\
{[0.025]} \\
(5.93)^{* * *}\end{array}$ & $\begin{array}{c}0.296 \\
{[0.064]} \\
(7.85)^{* * *}\end{array}$ & $\begin{array}{l}0.349 \\
{[0.116]} \\
(10.70) * * *\end{array}$ & $\begin{array}{c}0.361 \\
{[0.057]} \\
(8.86)^{* * *}\end{array}$ & $\begin{array}{c}0.360 \\
{[0.089]} \\
(10.40)^{* * *}\end{array}$ & $\begin{array}{c}0.344 \\
{[0.023]} \\
(5.79)^{* * *}\end{array}$ \\
\hline Women & $\begin{array}{c}0.481 \\
{[0.047]} \\
(4.32)^{* * *}\end{array}$ & $\begin{array}{c}0.353 \\
{[0.080]} \\
(4.97)^{* * *} \\
\end{array}$ & $\begin{array}{l}0.530 \\
{[0.175]} \\
(9.25)^{* * *}\end{array}$ & $\begin{array}{c}0.271 \\
{[0.043]} \\
(3.23) * * *\end{array}$ & $\begin{array}{c}0.103 \\
{[0.024]} \\
(1.54)\end{array}$ & $\begin{array}{c}0.356 \\
{[0.026]} \\
(2.87) * * *\end{array}$ \\
\hline Log likelihood & \multicolumn{6}{|c|}{-28078.4} \\
\hline \multicolumn{7}{|c|}{ Correlation of error terms } \\
\hline Child Care & $\begin{array}{c}0.287 \\
(11.73)^{* * *}\end{array}$ & --- & --- & --- & --- & --- \\
\hline Flexibility & $\begin{array}{c}0.291 \\
(12.63)^{* * *}\end{array}$ & $\begin{array}{c}0.340 \\
(21.63)^{* * *}\end{array}$ & --- & --- & --- & --- \\
\hline Relatives & $\begin{array}{c}0.344 \\
(13.17)^{* * *} \\
\end{array}$ & $\begin{array}{c}0.516 \\
(30.16)^{* * *} \\
\end{array}$ & $\begin{array}{c}0.418 \\
(23.82) * * * \\
\end{array}$ & --- & --- & --- \\
\hline Leave & $\begin{array}{c}0.329 \\
(14.31)^{* * *}\end{array}$ & $\begin{array}{c}0.318 \\
(18.68)^{* * *}\end{array}$ & $\begin{array}{c}0.426 \\
(30.12)^{* * *}\end{array}$ & $\begin{array}{c}0.364 \\
(20.76)^{* * *}\end{array}$ & --- & --- \\
\hline Network & $\begin{array}{c}0.370 \\
(11.65)^{* * *}\end{array}$ & $\begin{array}{c}0.433 \\
(16.74)^{* * *}\end{array}$ & $\begin{array}{c}0.357 \\
(12.56) * * *\end{array}$ & $\begin{array}{c}0.461 \\
(18.18)^{* * *}\end{array}$ & $\begin{array}{c}0.341 \\
(12.98) * * *\end{array}$ & --- \\
\hline $\mathrm{N}$ & \multicolumn{6}{|c|}{16391} \\
\hline
\end{tabular}

Method: Multivariate Probit. The table shows the estimated coefficients. Z-statistics in parentheses are based on standard errors clustered at the establishment level. Average marginal effects are in square brackets. *** Statistically significant at the $1 \%$ level; ** 5\% level; * 10\% level. Control variables are included, but are suppressed to save space. 
Table 3: Controlling for the Wage Level

\begin{tabular}{|c|c|c|c|c|c|c|}
\hline & Advancement & Child care & Flexibility & Relatives & Leave & Network \\
\hline Works council & $\begin{array}{c}0.278 \\
{[0.019]} \\
(4.33)^{* * *}\end{array}$ & $\begin{array}{c}0.206 \\
{[0.043]} \\
(4.52)^{* * *}\end{array}$ & $\begin{array}{c}0.408 \\
{[0.139]} \\
(10.30)^{* * *}\end{array}$ & $\begin{array}{c}0.416 \\
{[0.062]} \\
(8.59)^{* * *}\end{array}$ & $\begin{array}{c}0.317 \\
{[0.075]} \\
(7.64)^{* * *}\end{array}$ & $\begin{array}{c}0.604 \\
{[0.037]} \\
(9.07)^{* * *}\end{array}$ \\
\hline Wage level & --- & --- & --- & --- & --- & -- \\
\hline Log likelihood & \multicolumn{6}{|c|}{-22684.1} \\
\hline \multirow[t]{2}{*}{$\mathrm{N}$} & \multicolumn{6}{|c|}{13363} \\
\hline & Advancement & Child care & Flexibility & Relatives & Leave & Network \\
\hline Works council & $\begin{array}{c}0.235 \\
{[0.016]} \\
(3.57) * * *\end{array}$ & $\begin{array}{c}0.165 \\
{[0.034]} \\
(3.57)^{* * *}\end{array}$ & $\begin{array}{c}0.355 \\
{[0.120]} \\
(8.88)^{* * *}\end{array}$ & $\begin{array}{c}0.374 \\
{[0.054]} \\
(7.61)^{* * *}\end{array}$ & $\begin{array}{c}0.293 \\
{[0.068]} \\
(6.91)^{* * *}\end{array}$ & $\begin{array}{c}0.590 \\
{[0.036]} \\
(8.58)^{* * *}\end{array}$ \\
\hline Wage level & $\begin{array}{c}0.097 \\
{[0.006]} \\
(3.49)^{* * *}\end{array}$ & $\begin{array}{c}0.095 \\
{[0.019]} \\
(4.66)^{* * *}\end{array}$ & $\begin{array}{c}0.126 \\
{[0.041]} \\
(7.55)^{* * *} \\
\end{array}$ & $\begin{array}{c}0.098 \\
{[0.014]} \\
(4.41)^{* * *}\end{array}$ & $\begin{array}{c}0.055 \\
{[0.012]} \\
(2.96)^{* * *}\end{array}$ & $\begin{array}{c}0.031 \\
{[0.002]} \\
(0.95)^{* * *}\end{array}$ \\
\hline Log likelihood & \multicolumn{6}{|c|}{-22640.1} \\
\hline $\mathrm{N}$ & \multicolumn{6}{|c|}{13363} \\
\hline
\end{tabular}

Method: Multivariate Probit. The table shows the estimated coefficients. Z-statistics in parentheses are based on standard errors clustered at the establishment level. Average marginal effects are in square brackets. ${ }^{* * *}$ Statistically significant at the $1 \%$ level. Control variables and correlations of error terms are suppressed to save space. 
Table 4: The Issue of Endogeneity

\begin{tabular}{|c|c|c|c|c|c|c|c|}
\hline & Works council & Advancement & Child care & Flexibility & Relatives & Leave & Network \\
\hline Works council & --- & $\begin{array}{c}0.436 \\
{[0.034]} \\
(4.11)^{* * *}\end{array}$ & $\begin{array}{c}0.309 \\
{[0.064]} \\
(3.87)^{* * *}\end{array}$ & $\begin{array}{c}0.536 \\
{[0.184]} \\
(8.32)^{* * *}\end{array}$ & $\begin{array}{c}0.624 \\
{[0.100]} \\
(6.67)^{* * *}\end{array}$ & $\begin{array}{c}0.397 \\
{[0.095]} \\
(5.76)^{* * *}\end{array}$ & $\begin{array}{c}0.834 \\
{[0.056]} \\
(7.88)^{* * *}\end{array}$ \\
\hline $\begin{array}{l}\text { Works council share } \\
\text { (industry and } \\
\text { region) }\end{array}$ & $\begin{array}{c}2.795 \\
{[0.500]} \\
(22.24)^{* * *}\end{array}$ & --- & --- & --- & --- & --- & --- \\
\hline Log likelihood & \multicolumn{7}{|c|}{-32064.8} \\
\hline \multicolumn{8}{|c|}{ Correlation of error terms } \\
\hline Works council & --- & $\begin{array}{c}-0.117 \\
(1.95)^{*}\end{array}$ & $\begin{array}{c}-0.116 \\
(2.41)^{* *}\end{array}$ & $\begin{array}{c}-0.127 \\
(3.24)^{* * *}\end{array}$ & $\begin{array}{c}-0.164 \\
(2.86) * * * \\
\end{array}$ & $\begin{array}{c}-0.115 \\
(2.76)^{* * *} \\
\end{array}$ & $\begin{array}{c}-0.243 \\
(4.13) * * * \\
\end{array}$ \\
\hline $\mathrm{N}$ & \multicolumn{7}{|c|}{16391} \\
\hline
\end{tabular}

Method: Recursive Multivariate Probit. The table shows the estimated coefficients. Z-statistics in parentheses are based on standard errors clustered at the establishment level. Average marginal effects are in square brackets. *** Statistically significant at the $1 \%$ level; ** 5\% level; * 10\% level. Control variables and the other correlations of error terms are suppressed to save space. 
Table 5: Separate Estimations by Collective Bargaining Status

\begin{tabular}{|c|c|c|c|c|c|c|c|}
\hline \multicolumn{8}{|c|}{ Only establishments covered by industry-level collective bargaining agreements } \\
\hline & Works council & Advancement & Child care & Flexibility & Relatives & Leave & Network \\
\hline Works council & --- & $\begin{array}{c}0.756 \\
{[0.069]} \\
(4.71)^{* * *}\end{array}$ & $\begin{array}{c}0.294 \\
{[0.055]} \\
(2.19) * * \\
\end{array}$ & $\begin{array}{c}0.547 \\
{[0.183]} \\
(5.88)^{* * *} \\
\end{array}$ & $\begin{array}{c}0.708 \\
{[0.112]} \\
(4.66) * * *\end{array}$ & $\begin{array}{c}0.562 \\
{[0.146]} \\
(4.69)^{* * *}\end{array}$ & $\begin{array}{c}1.062 \\
{[0.082]} \\
(5.91)^{* * *}\end{array}$ \\
\hline $\begin{array}{l}\text { Works council share } \\
\text { (industry and region) }\end{array}$ & $\begin{array}{c}3.303 \\
{[0.472]} \\
(14.82)^{* * *}\end{array}$ & --- & --- & --- & --- & --- & --- \\
\hline Log likelihood & \multicolumn{7}{|c|}{-11064.7} \\
\hline \multicolumn{8}{|c|}{ Correlation of error terms } \\
\hline Works council & -- & $\begin{array}{l}-0.236 \\
(2.61)^{* *}\end{array}$ & $\begin{array}{r}-0.140 \\
(1.60) \\
\end{array}$ & $\begin{array}{c}-0.140 \\
(2.56)^{* *} \\
\end{array}$ & $\begin{array}{l}-0.163 \\
(1.68)^{*}\end{array}$ & $\begin{array}{c}-0.180 \\
(2.36)^{* *}\end{array}$ & $\begin{array}{c}-0.325 \\
(2.93)^{* * *}\end{array}$ \\
\hline $\mathrm{N}$ & \multicolumn{7}{|c|}{5420} \\
\hline \multicolumn{8}{|c|}{ Only establishments covered by firm-level collective bargaining agreements } \\
\hline & Works council & Advancement & Child care & Flexibility & Relatives & Leave & Network \\
\hline Works council & --- & $\begin{array}{c}-0.422 \\
{[-0.057]} \\
(0.29) \\
\end{array}$ & $\begin{array}{c}0.024 \\
{[0.005]} \\
(0.07) \\
\end{array}$ & $\begin{array}{c}0.281 \\
{[0.095]} \\
(0.43) \\
\end{array}$ & $\begin{array}{c}0.383 \\
{[0.078]} \\
(0.85) \\
\end{array}$ & $\begin{array}{c}0.202 \\
{[0.059]} \\
(0.29) \\
\end{array}$ & $\begin{array}{c}0.862 \\
{[0.076]} \\
(1.70)^{*} \\
\end{array}$ \\
\hline $\begin{array}{l}\text { Works council share } \\
\text { (industry and region) }\end{array}$ & $\begin{array}{c}3.047 \\
{[0.268]} \\
(6.79)^{* * *} \\
\end{array}$ & --- & --- & --- & --- & --- & --- \\
\hline Log likelihood & \multicolumn{7}{|c|}{-2547.8} \\
\hline \multicolumn{8}{|c|}{ Correlation of error terms } \\
\hline Works council & --- & $\begin{array}{l}0.356 \\
(0.42)\end{array}$ & $\begin{array}{l}0.003 \\
(0.01)\end{array}$ & $\begin{array}{l}0.050 \\
(0.12)\end{array}$ & $\begin{array}{c}-0.1334 \\
(0.48) \\
\end{array}$ & $\begin{array}{l}0.104 \\
(0.23)\end{array}$ & $\begin{array}{l}-0.112 \\
(0.37)\end{array}$ \\
\hline $\mathrm{N}$ & \multicolumn{7}{|c|}{1022} \\
\hline \multicolumn{8}{|c|}{$\begin{array}{l}\text { Only establishments not formally bound to a collective bargaining agreement } \\
\text { (with or without an informal orientation at an agreement) }\end{array}$} \\
\hline & Works council & Advancement & Child care & Flexibility & Relatives & Leave & Network \\
\hline Works council & --- & $\begin{array}{c}-0.146 \\
{[-0.007]} \\
(0.83) \\
\end{array}$ & $\begin{array}{c}-0.112 \\
{[-0.021]} \\
(0.97)\end{array}$ & $\begin{array}{c}0.184 \\
{[0.061]} \\
(1.64) \\
\end{array}$ & $\begin{array}{c}0.082 \\
{[0.009]} \\
(0.59) \\
\end{array}$ & $\begin{array}{c}-0.181 \\
{[-0.033]} \\
(1.43) \\
\end{array}$ & $\begin{array}{c}0.489 \\
{[0.021]} \\
(2.90)^{* * *} \\
\end{array}$ \\
\hline $\begin{array}{l}\text { Works council share } \\
\text { (industry and region) }\end{array}$ & $\begin{array}{c}2.208 \\
{[0.408]} \\
(13.23)^{* * *} \\
\end{array}$ & $\overline{---}$ & --- & --- & --- & $\begin{array}{ll}-- \\
-1\end{array}$ & --- \\
\hline Log likelihood & \multicolumn{7}{|c|}{-17673.9} \\
\hline \multicolumn{8}{|c|}{ Correlation of error terms } \\
\hline Works council & -- & $\begin{array}{l}0.145 \\
(1.53) \\
\end{array}$ & $\begin{array}{c}0.108 \\
(1.72)^{*}\end{array}$ & $\begin{array}{l}0.013 \\
(0.20) \\
\end{array}$ & $\begin{array}{l}0.084 \\
(1.13) \\
\end{array}$ & $\begin{array}{c}0.150 \\
(2.07)^{* *}\end{array}$ & $\begin{array}{l}-0.108 \\
(1.24) \\
\end{array}$ \\
\hline $\mathrm{N}$ & \multicolumn{7}{|c|}{9949} \\
\hline
\end{tabular}

Method: Recursive Multivariate Probit. The table shows the estimated coefficients. Z-statistics in parentheses are based on standard errors clustered at the establishment level. Average marginal effects are in square brackets. *** Statistically significant at the $1 \%$ level; ** 5\% level; * $10 \%$ level. Control variables and the other correlations of error terms are suppressed to save space. 


\section{Endnotes}

${ }^{1}$ See also the studies by Black et al. (1999), Brookes et al. (2001), Hübler (2005) and Jirjahn and Stephan (2004).

${ }^{2}$ As emphasized by Bertrand et al. (2005), discrimination can occur explicitly or implicitly. Explicit discrimination means that individuals consciously discriminate based on their preferences and beliefs. By contrast, implicit discrimination is unintentional and outside of the discriminator's awareness. Such implicit discrimination is based on unconscious mental associations leading people to think, feel and behave in ways that oppose their explicitly expressed views.

3 Rudman (1998) and Rudman and Fairchild (2004) find that women who self-promote in a stereotypically masculine way are perceived to be socially less competent. Bowles et al. (2007) show that men are more willing to work with women who simply accept wage offers than with women who attempt to negotiate for higher wages. If women start negotiations, this may be viewed as a violation of norms of politeness that socially less powerful employees have to abide by.

${ }^{4}$ Ross and Mirowsky (1988) show that difficulty in arranging child care dramatically reduces the psychological well-being of working mothers but has no effect on husbands. Relatedly, Coverman and Sheley (1986) find that fathers spend little time with their children regardless of the mother's labor force participation.

${ }^{5}$ There can be situations in which the potential benefits of OGPs exceed the costs, but the potential benefits can only be fully realized with the help of employee representation. We refer to these situations as organizational failure situations. In these situations, organizational mechanisms such as unilateral management decisions or individual-level bargaining between employees and management are not enough to realize sufficiently high benefits of OGPs. Thus, OGPs are not provided without a works council. A works council helps that OGPs live up to their potential and, hence, increases their benefits. Of course, this does not mean that a works council makes OGPs optimal for all establishments. However, the council should increase the probability that the benefits exceed the costs.

${ }^{6}$ By excluding government agencies and non-profit organizations, we focus on commercial establishments. These establishments may be privately or publicly owned. 
${ }^{7} 4,080$ establishments participated in both the 2012 and the 2016 wave, 4,336 in the 2012 wave only, and 3,895 in the 2016 wave only.

${ }^{8}$ There are 2.4 percent of establishments with both a works council and alternative employee representation, 22.1 percent with a works council only and 10.6 percent with alternative employee representation only.

${ }^{9}$ A more detailed discussion on the explanatory variables can be found in Jirjahn and Mohrenweiser (2019). With some exceptions, our choice of explanatory variables is oriented at the specification used by Heywood and Jirjahn (2009). Due to lack of information in the 2012 and 2016 wave of the survey, we do not include variables for job characteristics. However, we can additionally control for product market competition, shift work and weekly hours. Moreover, we capture industrial relations in more detail by including variables for orientation at collective bargaining contracts and alternative nonunion employee representation in addition to the variables for collective bargaining coverage and works councils. We note that some studies try to group the determinants of OGPs in broad categories. Osterman (1995) distinguishes between practical responses, internal labor markets and highcommitment work systems. Budd and Mumford (2004) distinguish between economic theories, internal labor market explanations and institutional theories. As recognized by Budd and Mumford (2006), there is much overlap across these categories limiting the ability to empirically differentiate between the categories. Thus, without grouping the variables, they look for a reasonable set of explanatory variables that can be used as predictors of OGPs. We follow this approach.

${ }^{10}$ The estimates were performed in STATA using a program written by Capellari and Jenkins (2003).

${ }^{11}$ For the purpose of comparison, we also estimated simple univariate probit regressions that ignore the correlation of error terms between the various equations. As shown in Table A4, these regressions yield similar results on the key explanatory variables. However, the multivariate probit model has to be preferred as the error terms are correlated.

${ }^{12}$ As the shares of establishments promoting the advancement of women and participating in a network of family-friendly companies is relatively low, we also performed Firth's logit regressions with these two variables to check the robustness of results. As shown in Table A5, this robustness check confirms 
our key pattern of results. Note that the table does not provide marginal effects as STATA has no command to calculate marginal effects for the Firth's logit model.

${ }^{13}$ Works councils incidence is positively correlated with establishment size. Thus, as a check of robustness, some studies exclude small and large establishments from the analysis. However, the thresholds vary across studies. Building from Müller (2012), we additionally provide estimates for establishments with between 21 and 300 employees. The key results are shown in Table A6. With the exception of the provision of child care, this exercise confirms that works councils are positively associated with the provision of OGPs.

${ }^{14}$ These estimates based on the smaller sample can also be compared with the estimates based on the full sample in Table 3. The comparison shows that we obtain very similar results on the works council variable. Thus, there is no evidence that the estimates on the works council variable suffer from a sample selection bias when we exclude observations with missing information on the wage level. Additionally, we estimated the determinants of providing information on the wage level. The results are shown in Table A7. Works council incidence is not significantly associated with the likelihood of providing information on wages. This can be seen as a further indication that the estimates on the works council variable in Table 4 are not subject to a sample selection bias.

${ }^{15}$ In using the term 'incompetent managers' we follow FitzRoy and Kraft (1987).

${ }^{16}$ If information on incompetent managers was available in the data, a corresponding variable could be included in the regressions. The estimated coefficient on that variable would probably show the negative influence of incompetent management on the likelihood of the provision of OGPs. Hence, the coefficient on the works council variable would capture the true positive effect of works councils on OGPs. However, information on poor management is not available. To the extent works councils are more likely to be present in establishments with incompetent managers, omission of the variable for incompetent management implies that the coefficient on the works council variable underestimates the true effect of works councils. The coefficient not only captures the positive effect of works councils, but also the negative effect of incompetent managers.

17 Previous studies have applied similar aggregation identification strategies in other contexts (Bilanakos et al. 2018, Cornelissen et al. 2011, Jirjahn and Mohrenweiser 2016, Jirjahn and Müller 2014, Lee 2004, Machin and Wadhwani 1991, Woessmann and West 2006). 
${ }^{18}$ Let us use the example of shift work to illustrate this point. Shift work and works council incidence are positively associated (Jirjahn 2008); and the use of shift work varies across industries. Thus, the share of works councils within an industry might partially reflect the propensity to use shift work. A high propensity to use shift work makes it more likely that a firm implements family-friendly practices as working at unusual hours requires that employees can reconcile work and family. Thus, if we do not control for the establishment's use of shift work, there might be a direct link between the instrumental variable and the firm's provision of OGPs. By contrast, if the establishment's use of shift work is controlled for, the instrumental variable should only have an indirect influence by having an impact on the likelihood that a works council is present.

${ }^{19}$ Studies on employment growth and productivity also suggest that estimates of the performanceenhancing effects of works councils are larger when the endogeneity of works council incidence is accounted for (Jirjahn 2010, Müller 2012).

${ }^{20}$ In order to improve convergence of the regression, we do not perform separate estimates for uncovered establishments with and without orientation at a collective bargaining agreement.

${ }^{21}$ Works councils not only have an influence on OGPs. They have an influence on the personnel policy of establishments in various dimensions (see Jirjahn and Smith 2018 and Jirjahn 2018 for surveys). Establishments with works councils have larger internal labor markets, provide more training and are more likely adopt performance pay and profit sharing. On the one hand, this suggests that information sharing and solving commitment problems play a role in a series of HRM practices. On the other hand, this might indicate a uniform formalization of personnel policy through works councils. However, we note that there is evidence that works councils not only increase the use of the various HRM practices, but also improve the performance-enhancing effects of practices such as profit sharing or training (Hinz and Mohrenweiser 2019, Jirjahn 1998, 2018, Smith 2006, Zwick 2004, 2008). Thus, the influence of works councils appears to be more than a simple formalization of personnel policy. 